\title{
The Whole Greater than the Sum of Its Parts: An Investigation into the Existence of European Identity, Its Unity and Its Divisions
}

\author{
Ruxandra Trandafoiu \\ Edge Hill University
}

Keywords: $\quad$ Europeanization, Euroscepticism, Enlargement, Migrant Workers, New Media

\begin{abstract}
The article offers an alternative stance to established research emphasising the absence of a European public sphere and the presence of Euroscepticism both in the media and public opinion at large. Whereas these are recognised and proven phenomena, the article argues that a perpetual, albeit evolving, cosmopolitan European identity is being reproduced as part of the natural process of globalisation. Europeanness finds some of its fresh strength in phenomena such as work migration. Although migration for work is by no means a new occurrence, Eastern European work diasporas participate in the construction of a renewed idea of Europe through new networks of communication supported by new media technologies which, although not mainstream, appear to gather strength and will become indispensable to the way new spaces of European identity are articulated.
\end{abstract}

\section{Introduction}

The article criticises the current 'doom and gloom' that permeates European studies in the context of widespread Euroscepticism and acerbic criticism of the enlargement process. The article argues that both Eurosceptics and those proEuropeans, who remain concerned about the apparent absence of a European public sphere, often overlook that European identity is a well established, alive and more desirable than ever presence, its existence proven by some important phenomena and characteristics that are being discussed here. The visibility of Europeanness is nevertheless hampered by its inherent symbolism and a subtle process of imagining which is not always mainstream and visible.

In order to make apparent some of the overlooked signs of Europeanization, the article proposes an example of the viability and inevitability of the process, with reference to Romanian work migrants. Diasporic groups such as these use new

Westminster Papers in Communication and Culture (C) 2006 (University of Westminster, London), Vol. 3(3): 91-108. ISSN 1744-6708 (Print); 1744-6716 (Online) 
media to construct new symbolic geographies, which are supranational and cosmopolitan in nature, more adjusted to a European identity which is in a constant process of modernisation and updating. Based on one month monitoring of three Romanian websites in the UK and Italy, the article unpacks some of the characteristics of diasporic websites in an attempt to judge their political potential and the possible boost and clarification grassroots phenomena like these can offer the European idea.

\section{Europeanization: Dilemmas and Sceptical Voices}

Academics seem to be in agreement that the process of constructing a European identity is not working. The causes found are varied, from the democratic deficit created by the slow and convoluted wheel of EU bureaucracy, to widespread Euroscepticism and the absence of a European wide public sphere usually blamed on the incapacity of the media to 'sell' the idea of Europe. To give just an example, one particularly bleak view results from John Gillingham's historical account of fifty years of European integration where he blames what he considers to be the present crisis of the Union on poor leadership, economic weakness and faulty functioning of institutions (Gillingham 2003, 482).

But is this apparently monolithic Euroscepticism all pervading and more importantly is it justified? The British case seems to confirm it. With the refusal to adopt the Euro, diffidence towards embracing an EU Constitution, openly antiEuropean politicians and Europhobic press, Britain seems to be among the most Eurosceptic countries in Europe. Some of the main causes of British Euroscepticism have been aptly explored by Anderson and Weymouth in their 1999 book where they give a complex picture of the reasons behind antiEuropeanism in the British press including: the UK is physically separated from the continent and does not have an experience of hostile occupation or military defeat like the rest of continental Europe; there are currently not many speakers of foreign languages and there is evidence of lack of engagement with other cultures; there are residues of imperial superiority and embarrassment over UK's reduced influence in an EU dominated by France and Germany; Labour and Tory self interested politics; the UK media being dominated by often non-European owners, lack of specialised knowledge and low journalism standards, as well as the dominance of commercialism (Anderson and Weymouth 1999).

While these are perfectly valid points - with the note that some of these phenomena are not necessarily set, but changing in time - the study conducted by Anderson and Weymouth on the London based press also reflects that at least an important part of the quality press displays a certain degree of pro-Europeanism evident in the excellent economic coverage of the EU in newspapers such as the Independent, Guardian or Financial Times (Anderson and Weymouth 1999, 93-112). 
Such instances in which the EU is discussed objectively and with an open mind towards its benefits for the UK citizens is an important sign that inevitably British Euroscepticism is slowly starting to be counteracted. Far from being monolithic, national public spheres are divided and fragmented, with competing versions of Europe appearing under the banner of different political factions. Therefore the 'pro-European camp' is not as minimal and isolated as Eurosceptics assume.

Euroscepticism is not necessarily an exclusive British trait either, nor are most of the phenomena Anderson and Weymouth observe, with the exception possibly of the historical causes they mention. The provincialism and lack of vision of political elites and the journalists' ignorance of European matters are European wide grievances. As Lewis and Wahl-Jorgensen explain, 'public opinion thus plays a minimal role in driving the news agenda. The agenda is set by politicians and other elites. As such, politics on the news is usually about what politicians do, and not necessarily about what people want them to do. For instance, in the British 2001 election, the issue on which public opinion was most often cited was that of the country's future in the European Union [...yet] issue polls conducted at the same time showed that most people ranked Europe as a relatively unimportant topic $[\ldots]$ while sections of the British press were strongly anti-Europe, making public opinion on the issue 'relevant' to the political debate' $(2005,101)$. Often Europe becomes a hobbyhorse not because politicians have something interesting to say about it, but they need to artificially reinforce a perception that it is already little understood and often mistrusted by the general public opinion. The lack of political vision and European leadership only adds to the EU's problems.

Most recently Europhobia has been expressed in the context of EU enlargement. Euroscepticism was never more obvious than in May 2004 at the time of the biggest EU enlargement when an analysis of its coverage in the daily and Sunday newspapers (The Sun, The News of the World, The Daily Mail, The Mail on Sunday, The Independent, The Independent on Sunday, The Financial Times and Business) carried out between 26 April and 9 May revealed that Euroscepticism was expressed under four main headings: the political implications of a legal system in chaos; the economic costs of the enlargement; the abuse of social services and perceived negative cultural features displayed by Eastern European populations (Trandafoiu forthcoming). Although the content analysis of the enlargement revealed only predicted results and confirmed Anderson and Weymouth's findings on the dominance of economic implications in the quality press - The Financial Times had three times more coverage in column length than The Independent, which seems to not only confirm The Financial Times as the most reliable source of European news, but also that the EU is still predominantly viewed as an economic and not political union - the research highlighted once more the parochialism of the national press. While some of the topics raised were valid issues related to the impact of Eastern European work migrants on the social and economic system in Britain and also 
questioned the society's capability to approach multiculturalism and integration, sensationalised reporting in the right wing tabloid press in particular and instances of racism expressed in strong metaphors of otherness display a tendency on the part of journalists and editors to capitalise too on the lack of popularity afflicting the EU and construct an ethnocentric narrative of belonging.

EU reporting is dictated by national concerns and the welfare of national citizens is overemphasised, with very little European wide perspectives. The fact that tabloids like The Sun and The Mail totalled together as much as The Independent in column length, despite their slimmer formats, brought again into attention instances of discrimination and artificial racialisation of Eastern Europeans which is justified, as Anderson and Weymouth (1999) explain, by the commercialism of the tabloid press, as well as the lack of resources and trained editors and reporters when it comes to EU matters. This is not just typical for the UK. Other researchers too have emphasised that national perspectives still dominate despite of the standardization of advertising throughout Europe, increased reporting of European events and shared sporting occasions (Williams 2005, 149). It seems that pro-European academics, politicians and journalists should be preoccupied with 'finding the appropriate forms for the democratic process to take beyond the nationstate' (Habermas 2001a, 61), so that stories can be told within a European frame of reference and public sphere mechanisms can be translated at a supranational level. But how can this be accomplished?

An analysis of Habermas's concept of the lifeworld and its theoretical roots offers David Ward an understanding of why the translation from nation-state to the European dimension remains problematic. Ward considers that 'the democratic deficit and the lack of public identification with the European Union is essentially bound up with communication and the lack of, not only more accountable systems of governance, but more profoundly, discursive structures, which make political community possible' (Ward 2002, 18). Most of the EU's initial media projects like the failed Europa television channel and the Television without Frontiers Directive, which never accomplished its full potential, could be categorized as 'idealistic' (Ibid, 45) and Ward considers that the implementation of such initiatives will continue to pose challenges. The economic tension at the heart of broadcasting, which invariably means that public service gives way to commercial competition, has also affected channels like Euronews, which in addition has also suffered from lack of identity (Casero 2005). Limited access to satellite communication, advertising to culturally heterogeneous audiences, culturally defined viewing habits and multilingualism (Ibid) are affecting the creation of a unique communicative space.

So far these accounts have focused on more traditional media forms, if one is also to consider satellite as an already established 'older' form. Far less accounts exist 
on the role of new media, such as the Internet and mobile phones, in the construction of European networks. This is not only due to the apparent fragmented nature of such technologies, but also because new media is less policy driven and elite led, and more a grassroots phenomenon, hence it is more difficult to investigate and has a less apparent impact.

The impotence felt by politicians and media scholars when dealing with the creation of European media, which is able to generate and reproduce a common identity, is an old grievance that Philip Schlesinger (2003) tries to address in his article. Metaphorically depicting Europe as a 'Babel' of cultural and linguistic diversity Schlesinger answers any traditional concerns by referring to a number of current phenomena, which seem to imply that the seeds of Europeanization will simply not wither. The emergence of English as a 'lingua franca', common public responses to international events as 'nations, responding as singular national publics' that have proved to be 'substantially united in their opposition to war' (Schlesinger 2003, 4), work mobility, the interesting interplay between international and regional publics, new supra and sub-national networks of debate and communication, even shopping and tourism, as well as news reporting create a new European frame of reference, despite the sturdiness of national frames.

It may be that pro-Europeans are trying too hard to artificially recreate what already exists in less obvious forms. Looking at Europe from such perspectives makes unifying policies such as Europa seem indeed utopian. Yet, by trying to explore what this means not from a macro but a micro view, it is important to note than even when projects under deliver or gain a life of their own with unpredicted consequences (even when Euroscepticism seems to dominate national discourses), it is important that Europe remains a point of discussion, proof of the existence of a European public sphere of debate formed by smaller maybe diverging spheres which even when nationally or regionally defined have a European frame of reference. The picture is far less bleak than academics try to portray it and it is certainly more appropriate to imagine the EU as constituted by a multiplicity of communicative spaces than to think of it as having one, overarching public sphere' (Schlesinger and Fossum 2005, 44).

Taking the example of the launch of the euro in the Italian media, Triandafyllidou concludes that the coverage of such events in the national media indicates 'the media link, in different combinations, national and European elements in representing the nation, the EU and the relationship between them' (Triandafyllidou 2003, 261), from a 'battlefield between competing national interests and state powers', to national identity 'represented as compatible with the emergence of an autonomous EU sovereignty and identity' (Ibid). More and more international events cannot be seen without the link between the national and European frameworks of reference. 'To varying degrees, all national identities in 
Europe contain elements of a European identity, which is not an identity that exists beyond or outside national identities' (Delanty and Rumford 2005, 54). Delanty urges that national identity be viewed as a broader concept which brings with it echoes of Bauman's 'liquid identity' (Bauman 2004, 2005) when he establishes that 'the European space has grown to the extent that it is no longer possible to say what is national and what is European [...] All national identities are becoming more like societal identities, that is, broadly defined cultural categories' (Delanty and Rumford 2005, 53).

The field seems to be split between a view that would like a European identity built solidly through institutions and policies and drawing strength from a natural cultural communion that needs to be promoted through gradual elite coordination, and the alternative of seeing European identity as a fait accompli that will continue to gain strength through an organic and irreversible growth brought about by globalisation and the establishment of European networks that are inspired by particular interests and contemporary phenomena like work migration. Further more, even in the case of traditional media, where European trivial events and occurrences could be described as 'forms without content', devoid of signs of Europeanism, they are in fact manifestations of a 'matter of fact' European identity, which in time is going to acquire synchronicity and structure.

The data obtained by Downey and Koenig when they analysed the 'BerlusconiSchultz' exchange in the European Parliament and its coverage in six EU member states, US, Canada and Switzerland does not indicate a 'European transcendence of national publics' due to the absence of a 'Europe-wide news agenda that is part of everyday media consumption of large audiences across nation-states' (Downey and Koenig 2006, 165). In addition, Eriksen finds that even though there 'are traits of a general public sphere in which all the citizens of the EU can take part, more salient are segmented publics evolving around policy networks, as well as legally institutionalised discourses -strong publics- specialized in collective will formation' (Eriksen 2005, 358). Yet, 'even though the problem of fragmentation and communication distortions prevail, which makes opinion and collective will formation difficult, it is fair to say that the more publics, the more debate and critique' (Ibid).

To give a trivial example, the controversial poster campaign marking Austria's presidency of the EU in January 2006, which was hastily withdrawn amid accusations of 'artistic' pornography (Kraske and Langer 2006), created a vibrant sphere of debate in quite a few member states and candidates (e.g. Romania). Despite the mundane nature of the event, it is controversies like these that keep the European public sphere going. One could argue that such debates, while appearing to be shallow, lead - as they did on more than one occasion - to more complex discussions, in this particular case about European symbolism, EU 
accountability, European financial support for new upcoming European art and EU management of the political process. Forms and shells are hence gradually filled with content and meaning. As Habermas remarks, 'a real advance would be for national media to cover the substance of relevant controversies in the other countries, so that all the national public opinions converged on the same range of contributions to the same set of issues, regardless of their origin' (Habermas 2001b, 18). But although this happens only temporarily, 'the fact that these multiple, horizontal flows of communication have to pass through filters of translations does not reduce their essential significance' (Ibid, 19). Micro publics discuss events that all have a European significance, simultaneously, and with cross national references. So despite widespread worries about overwhelming scepticism and the future of the European project, several counter points need to be raised.

Events are increasingly discussed within a European framework, highlighting European implications and there are signs of public opinion leading journalists on some occasions. Hence grassroots and community led initiatives supported by new media technologies need more in depth study in the context of European studies especially as micro public spheres merge into a wider European narrative. It is maybe the right time to acknowledge the European project as an unstoppable process that works beyond EU institutions and policies.

Elite led initiatives have failed Europe, the latest example being a 'watered down', 'hybrid' and 'mongrel' Constitution, with 'something in the Constitution for everyone to hate' (Longman and Perez-Solorzano 2005, 27), so more than at any other time there is the need to discover 'the cultural substrate for a civil solidarity' (Habermas 2001a, 64). Such a substrate exists, but needs to be verbalised by discussing how a modern and contemporary relevant European identity can be brought to light, and intellectuals are more important than ever for such a process to take place.

\section{A Viable European Identity}

Before proceeding to the example of such a micro European network - the diasporic websites used by Romanian migrant workers - it is important to address another misconception, that of the absence or weakness of a European identity which could support the formation of European public spheres of communication and debate.

Historically, the dream of united Europe has deep reaching roots. Immanuel Kant's (1795) idea of United States of Europe as a guarantor of 'perpetual peace' provided the obvious inspiration for postbellum politicians. Such once utopian projects have been inspired by the acknowledgement of Europe's uniqueness, expressed in a historic process of European imagining. 
One problem is that the perception of this 'imagined community' (Anderson 1991) built around a number of characteristics has been diluted through their successful export so 'the EU is now caught in the contradictory situation of having to define a common European culture that is universal - but no so universal that it is global and thus not distinctively European - and at the same time does not negate national and regional cultures' (Delanty and Rumford 2005, 60). As Bauman puts it, imagining Europeanness means in fact that 'you have a lot of little pieces on the table which you hope to arrange in some meaningful whole - but the image which ought to emerge at the far end of your labour is not given in advance' (Bauman $2004,48)$ and there is in effect no end to the process.

So the main difficulty of acknowledging European identity rests in the very abstract nature of its existence and the openness of its vision. In the case of the formation of nation-states, an element of artificiality was needed, resulting in a process that, far from being natural, was partly elite driven, economically motivated and rationally put in motion with the help of mass education, capitalist mobility, 'invented traditions' and national media which reproduced national imagining (Weber 1979; Hroch 1985; Anderson 1991; Gellner 1983 and 1994; Smith 1998). Similarly, Europeanization needs a helping hand in the form of a 'dynamic of opening and closure' (Habermas 2001a, 82), that would entail accepting Europeanization as a form of globalisation, but also establishing certain boundaries with the aim of an 'abstract, legally constructed solidarity that reproduces itself through political participation' (Habermas 2001a, 76). Such limits could of course be in the official form of a European Constitution, but also set by the cultural and communicative reproduction of European principles.

Hence European identity could be viewed as a cluster of 'cosmopolitan identities' (Habermas 2001a, 76 and Delanty and Rumford 2005, 23) inspired by 'constitutional patriotism' (Habermas 2001a, 74). For Delanty and Rumford this means that it is possible to conceive of European identity as a cosmopolitan identity embodied in the pluralized cultural models of a societal identity rather than as a supra-national identity or an official EU identity that is in a relation of tension with national identities' (Delanty and Rumford 2005, 23). This view resolves the traditional tension between the national and the supranational, much debated by the Western press. So it follows that as a cosmopolitan identity 'European identity is a form of post-national self-understanding that expresses itself within, as much as beyond, national identities' (Ibid).

No more desperate is the need for a strong European identity evolving from both the top and from below, than in a context in which the world listens to the 'swan song' of United States' global domination. Strong European leadership supported by grassroots pacifist movements should provide Europe with a new 
distinctiveness in the context in which the United States has proved 'unworthy' and incapable of acting as a liberal power. Hence 'the transmission of the European miracle to the rest of the world has become Europe's new mission civilisatrice' (Kagan 2002). In his article Kagan writes about the ideological gap that is ever more apparent between Europe and the United States pointing out that 'Europe, because of its unique historical experience of the past half-century culminating in the past decade with the creation of the European Union - has developed a set of ideas and principles regarding the utility and morality of power different from the ideals and principles of Americans, who have not shared that experience' (Kagan 2002). Europeans rightly 'emphasize process over result, believing that ultimately process can become substance' (Ibid). This experience should spur Europe towards unifying its stance at a global level and presenting an alternative model, rooted in the Enlightenment experience that America has now relinquished.

So apart from internal processes, which are either elite or grassroots led, European identity can be expressed as a result of external developments. 'Much more frightening than the threat of international terrorism is the spectre of a divided and politically incoherent Europe, incapable of safeguarding the interests of her people in a world dominated by the US, China and India. Though Blair hates the very idea, the spectre can be kept at bay only if Europe becomes an alternative pole of power in an increasingly multipolar world' (Marquand 2004, 20). Calls for a new partnership between Europe and the United States that would strengthen Europe's 'collective voice' and weaken American 'unilateral impulse' have been multiplying particularly in the liberal press in Britain (Clark 2004, 23; Ferguson 2005, 16).

Such views echo those of philosophers like Hajime Nakamura (1993) who in his investigation of Western and Eastern thought and traditions (viewed comparatively and historically) ends with a note on the commonalities of problems and developments that all cultures seem to face, irrespective of how synchronically or diachronically they behave. In the age of globalisation, Nakamura seems to be saying, there is no reason why ideas cannot spread simultaneously, the world relatively harmonised for the first time. As a traditional exporter of universal ideas, Europe is once more in a strong position.

Despite of this openness, Europe nevertheless should close around certain principles that have characterised European thought since antiquity. Nakamura (1993) places the uniqueness of European philosophy in the idea of evolution and the spirit of experimentation. Other similarly traditional approaches enlist a long inventory of European characteristics that lie at the core of Europe's identity, such as doctrines stemming from ancient Greek and Roman cultures and the Christian religion (Pecican 2003, 27). More specifically, one could see democracy, liberal 
public sphere, rationality, sovereignty, law and administration, Christian love and the European social model based on equality and redistribution, among Europe's greatest and most successful export products. In addition, looking retrospectively at the evolution of Western societies over the past two centuries, six main commonalities emerge: the life and structure of the European family; the dominance of industrial employment; the class system and the social fabric; the welfare state and the mass consumer society (Kaelble 2004, 278-289), to which Habermas adds: 'The secularization of the egalitarian and individualist universalism that informs our normative self-understanding is not the least among the achievements of modern Europe' (Habermas 2001b, 20). The recognition these traits receive explains why for example even after fifty years of communism, Eastern European societies were able in just a few years to reaffirm their Europeanness, not displaying any significant cultural differences in comparison with their capitalist Western counterparts, sharing the same understanding of normative political culture and social structure. Respect for what the idea of Europe means in terms of democracy, welfare and modernity has always driven the enlargement process and has aided Eastern states to heal the scars of communism and surpass economic hardship.

Such conservative depictions of European identity might by now seem outdated. However, it is important for Europe to remember its own origins in order to come to terms with contemporary developments, which give its identity a modern, multicultural and cosmopolitan form. This historical approach highlights the fact that Europe is forever self-searching and changing in time. It is these reflective and shifting qualities that preserve the European idea fresh and legitimate for the future and makes it a better and viable alternative to a world dominated by illiberal and militarist powers.

But the traditionalist approach needs to be customized for contemporary purposes. Although Delanty and Rumford (2005) pick up on some of these principles, they offer a modernised view of European identity, as a sight of 'cosmopolitan' loyalties. A current European identity needs indeed to be cultivated around 'constitutional patriotism' and the sharing of a political culture, but only when accompanied by a common way of life and common cultural values: 'The euro and other examples from material life, such as sport, education exchanges, architecture and cityscapes and tourism, point to a tendentially European way of life in the sense of common patterns of life, symbolic structures and transnational discourses across Europe' (Delanty and Rumford 2005, 85). A European idea based on liberal political culture and communication is an idea inclusive enough to make Europe fit for the new global world, yet still distinctive in the characteristics that made Europe what it is. 
By finding a 'closure', an identity, even though a traditionalist one, the idea of Europe can secure the support of national governments, which is likely to happen because 'the European project can be seen as a common attempt by the national governments to recover in Brussels something of the capacity for intervention that they have lost at home' (Habermas 2001b, 14). Habermas (2001a) returns to this idea again and again, seeing the EU as a way in which national governments withstand the power of globalisation by joining it to some extent, and hence retaining some of their power and voice in the international arena, as a 'constellation' or a collective. This is inextricably linked to evolving new networks of communication, which are not as much policy driven, but stem from the natural potential of new technologies. European identity should therefore be 'sought in the cosmopolitan currents of European societies in which new forms of selfunderstanding are emerging [...] Identity is about giving voice, and this requires neither a clearly defined ethnos nor a demos but discursive spaces' (Delanty and Rumford 2005, 68).

This cluster of remarks is key to understanding the longevity of the European idea. Europeanness is an offspring of globalisation, but its openness is limited by the continuing salience of the nation-state, which suits governments traditionally averse to loosing out to the supranational. Yet, this closure is not reactionary, but constantly evolving and diverse in nature.

To this extent, diasporas in Europe are fast becoming a classic example where a cosmopolitan European identity is being formed by mobile groups that transcend national spaces to form a 'third space' of interaction and communication, in which symbolism and community imagining play a key role.

\section{EU Enlargement and the In-Migration of the Workforce: Romanian Workers and Diasporic Websites}

Eastern European migrant workers represent a pertinent example of how cosmopolitan European identities can be naturally created, without policy or elite intervention. Migrants' experience of travel (real and symbolic) coupled with the use of new media technologies help form a group identity within a symbolic space that has Europe as its general frame of reference, while its content is multicultural and cosmopolitan. Migrant workers express their experience of different European cultures, social and legal systems and modes of interaction through diasporic websites. These are constructed to express such an understanding and the cosmopolitan European identity that results from it.

At the moment, such identities can remain 'hidden' from mainstream public sphere, but in time and with the predicted increase of the number of Eastern European workers in Western Europe, the new diasporic websites created to cater 
for their needs hold the potential to bring these identities into public view and give them a political voice in support of the European project which made the work migration possible in the first place. With the Internet and mobile phones already a mass phenomenon, it is now clear that new technologies hold a huge potential in the construction of identity and its political expression.

New media technologies are often blamed for the fragmentation of the public sphere, yet they establish communication networks as a prerequisite for the formation of group identity and offer the technological support for the process of mental migration (Sabry 2005) and imagining. Travel has long been modifying and defining ethnoscapes (Rantenen 2005, 143), aiding people to transcend locality. New media enhance the journey experience of work migrants and other forms of diasporas, supporting the repeated return, sometimes real, most often imagined. Such journeys of the mind (fuelled by actual real travel) trigger imagining in the form of symbolic geography, the mechanism through which a community sees itself in relation to others on a symbolic map, reproduces journey narratives and constantly reworks identity. As Brah observes, '[T] hese multiple journeys may configure into one journey via a confluence of narratives as it is lived and re-lived, produced, reproduced and transformed through individual as well as collective memory and re-memory' (Brah 1996, 183). In the case of the two million Romanian workers in Europe the narratives are constructed within the European space, with clear references to European identity.

Personal research presented at the International Communications Association annual Conference in Dresden (18-25 June 2006), but continued and extended since, analysed comparatively the main websites in Britain and Italy used by Romanian migrant workers and monitored chat exchanges and e-mail discussion groups for a month (5 June to 5 July 2006) in preparation for broadening the research to interviews. They comprised http://www.romani.co.uk/ and http://www.romani-online.co.uk/ in the UK (where the number of Romanians stands at 100,000) and http://www.italiaromania.com/ in Italy, the location of the largest group of Romanian workers, unofficially totalling one million. The analysis of the visual appearance and information content of the websites was followed by the examination of e-mail exchanges, the topics covered and the attitude of participants with regards to the diasporic community itself, its place in the host country, its relation with the home country, EU enlargement and any possible reflections on identity. This methodology was inspired by similar web research.

The analysis looked therefore at the 'architecture' of websites expressed in visual and content layering (Campbell 2004, 251). The richness of content was judged on the basis of its diversity comprising general information, news, context, analysis, commentary, discussion forums, feedback, archives, and links. It also looked at format and design, customisation and access, immediacy, hyperlinking and 
opportunities for interactivity (Gunter 2003, 65-72). It was important to note cultural markers that inspire website construction, what could be termed as the 'archaeology' of websites such as heritage, lifestyle, spiritual matters and their manifestation through symbolism. Text and images can construct online imaginaries (Chan 2005), since 'CMC [computer mediated communication] takes the migrant back home by creating and sustaining images through recipes, slideshows, community profiles and humour - all of which create an atmosphere of hyper-reality' (Hiller and Franz 2004, 746).

In view of the above methodology, one of the main findings is that these websites display remarkably common characteristics. The few differences observed are clearly the result of the size of the community, patterns or periods of migration and range of jobs performed by diasporas. For example, patriotism and nostalgia are expressed through stereotypical ethnic imagery of flags, maps and pictures of landmarks, such as churches, Dracula's castle, Danube Delta and Romanian folk costume. It seems that the websites attempt to conform to the expectations that outsiders might have upon imagining Romanianness. This is also the result of the diasporic arena being now highly commercialised and professionalized (Van Hear 1998, 257), evident in the way the home is sold in a stylised way.

Yet other local events and contexts override ethnocentric tendencies and the virtual diasporic space is opened up to include cross cultural and transnational markers. English and Italian flags appear on the websites and a wealth of news and links anchor the diaspora within the host space and the general European one. It verifies Siapera's findings that initially 'these websites seek to address and represent minority communities or publics in a singular, culturally enclosed way, thereby repeating the history and process of community formation with all its exclusions, essentialisms and simplifications. However [...] they cannot do so because of the character of the cyberspace environment, which resists this setting of clear boundaries' (Siapera 2006, 7).

News from the host countries but also referring to European decisions affecting migrants and the welfare of other Romanian groups in Europe is updated weekly, in response to obvious information needs and they blend naturally with home news. The discussion groups clustered around different topics reflect the same intermingling of European wide issues. The exchanges echo larger European debates linked with policy initiatives in the area of multiculturalism, social structure, employment and work ethics.

The discussions do not appear out of thin air, but are concerted by opinion makers within the groups. Based on Castells's theory of nodes and flows within the network and relationships between networks (Castells 2000, 501) it is manifest that such diasporic networks are dominated by 'geometries of power' (Dodge and 
Kitchin 2001, 55) apparent in the number of stars which label contributors and signal their capability to drive the debate in certain directions. Therefore 'newcomers' are labelled as such and their exchanges focus on obtaining information ensuring survival. In contrast, the more established migrant workers reflect on issues such as the national characteristic of the host populations, difficulties with integration, mixed marriages, perceptions of Romania and Romanians abroad, EU enlargement, East-West and self-other identities.

Diasporic discussion groups seemingly mimic 'real' communities, with rules, hierarchies and an insider versus outsider pattern, while also attempting selfempowerment and external assertiveness. Migrant workers attempt to understand their own position by conducting discursive practices and structuring narratives that position the group neither here nor there, but in a 'third space'. This 'third space' is cosmopolitan and European in nature.

While returns and visits to the geographical home continue to take place, the construction of home is mainly symbolical, inspired by a strong sense of nostalgia. The feeling of loss, the nostalgia and uprooting that come with the journey, real or imagined, fuel the establishing of a shelter which is culturally mobile and necessarily cosmopolitan in nature. Many media scholars emphasise the importance of communication networks for the 'new possibilities of being in two places at once' (Scannell 1996, 91), the opportunities of 'producing new spaces where remote localities and their experiences come together and become 'synchronised' (Tsagarousianou 2004, 62) and the ability to live at the same time in both the global and the local' (Rantanen 2005, 121). So home is experienced symbolically and synchronically, allowing it to travel together with the migrant and adjust accordingly.

As a result, the 'architecture' of these websites is complex and multilayered, with rich hyperlinking to encompass practical information (visa, driving a car in the UK, scholarships, recognition of Romanian qualifications, jobs) geared at 'newcomers' and links to host institutions and diasporic organisations catering for the more settled migrants. Criticism of current legal systems coming out of the chat and email exchanges carried out through these websites is the first step towards mobilising the community and expressing its group identity in political form. It is nevertheless early days due to the recent settlement of these communities and the mobility of some of its members who sometimes return home after short periods of time to be replaced by newcomers. But the websites attempt to establish a history of their own and insure continuation and survival with calls for activism whenever the pace of information exchange slows down.

The 'imagined community' constructed and remembered through certain cultural symbols means that 'locality is normally experienced symbolically; it consists of an 
imagined homeland or place understood through nostalgia, memory, history or constructed cultural sites and it is precisely this quality which enables such transnational communities to survive and remain viable for its members' (Kennedy and Roudometof 2003, 24). The combination between virtual 'third spaces' and elements of multiple localities can be translated at a political level. Reflection upon circumstances and the place of the group within the host community spur in time political activism, which can make the group visible. The multiplication of cosmopolitan voices within the European space of virtual communication networks can lead in time to actual civic networks of participation. From the website analysis it transpires that often the web communication leads to group encounters in different locations. The Internet space is not the place to hide difference or tuck away from public mainstream view whole communities, but the place where such communities gain strength, identity and visibility so that they start to count in the public arena where the tension between difference and universalism is articulated.

Diasporic research can therefore contribute to the theory of the interplay between private versus public spheres and its role in the construction of European identity. Eastern European migrant workers display the capability for mental travel and imagining necessary in envisaging European identity. They also have the necessary experience of travelling and working within Europe, exchanging ideas and customs, symbolically merging 'homes', carrying Western values back home, bringing Eastern experiences to the 'host'. Their use of new media to construct a cosmopolitan European identity can serve as an example of the unused potential of new technologies for the European project.

\section{Conclusion}

The simultaneous reporting of banal European events within the European space and the emerging identity of communities of migrant workers supported by new communication technologies, in particular websites, chat and mobile phones, can offer a response to Eurosceptics who deny the existence of Europeanness. The 'doom and gloom' concerns about the European project need to be reversed by focusing on phenomena that prove its vitality: pro-European media, reporting of European events sparkling European wide debates, informal trans-European networks of communication, virtual cosmopolitan spaces ('third spaces').

European identity has a symbolic dimension that makes the 'imagined community' difficult to envision, but this does not mean that it does not exist or that it cannot be translated at the level of common public opinion. Politicians, journalists and intellectuals need to coalesce their forces to that aim. European identity can be viewed as the interplay between the openness of globalisation and the closeness of a collective yet cosmopolitan identity, which is supported by states that see the EU 
as a vehicle for recuperating part of the power lost under the force of globalisation and the weakening of the nation-state. While the role of specific media and political or constitutional policies should not be underestimated and should be extended, political participation should also be reconsidered and read in the context of community inspired and local phenomena

Small European achievements in the form of banal debates carried on simultaneously at a national or regional level are expressions of a European public sphere gathering the strength of multiple smaller spheres that are nonetheless active and evolving within a clear European frame of reference. In this sense, the whole is greater than the sum of its parts. Grassroots initiatives by small localised or virtual publics must not be undervalued and their potential for political activism, providing equal European wide workers rights and similar approaches to managing multiculturalism needs to be acknowledged. Finally, the European potential of new media networks must be recognised and incorporated into future research.

\section{References}

Anderson, B. (1991) Imagined Communities, London: Verso.

Anderson, P. J. and A. Weymouth (1999) Insulting the Public? The British Press and the European Union, Harlow: Longman.

Bauman, Z. (2004) Liquid Life, Cambridge: Polity.

Bauman, Z. (2005) Identity, Cambridge: Polity.

Brah, A. (1996) Cartographies of Diaspora. Contesting Identities, London: Routledge.

Campbell, V. (2004) Information Age Journalism. Journalism in an International Context, London: Arnold.

Casero, A. (2005) 'European-wide Television and the Construction of European Identity. The Case of Euronews', available at http://www.iua.upf.es/formats/formats3/cas_a.htm (accessed 7 December 2005).

Castells, M. (2000) The Rise of the Network Society, Oxford: Blackwell.

Chan, B. (2005) 'Imagining the Homeland: The Internet and Diasporic Discourse of Nationalism', Journal of Communication Inquiry, 29(4): 336-368.

Clark, D. (2004) 'Stuck in the Middle', The Guardian, November 2, p. 23.

Delanty, G. and C. Rumford (2005) Rethinking Europe: Social Theory and the Implications of Europeanization, London: Routledge.

Dodge, M. and R. Kitchin (2001) Mapping Cyberspace, London: Routledge.

Downey, J. and T. Koenig (2006) 'Is There a European Public Sphere? The Berlusconi-Schulz Case', European Journal of Communication, 21(2): 165-187.

Eriksen, E. O. (2005) 'An Emerging European Public Sphere', European Journal of Social Theory, 8(3): 341-363.

Ferguson, N. (2005) 'Three Reasons Why the US and Europe Won't Make Up', The Guardian, February 21, p. 16. 
Trandafoiu, The Whole Greater than the Sum of Its Parts ...

Gellner, E. (1983) Nations and Nationalism, Ithaca: Cornell University Press.

Gellner, E. (1994) Encounters with Nationalism, Oxford: Blackwell.

Gillingham, J. (2003) European Integration 1950-2003. Superstate or New Market Economy, Cambridge University Press.

Gunter, B. (2003) News and the Net, London: Lawrence Erlbaum.

Habermas, J. (2001a) The Postnational Constellation: Political Essays. London: MIT Press.

Habermas, J. (2001b) 'Why Europe Needs a Constitution', New Left Review 11 SepOct, available at http://newleftreview.net/NLR24501.shtml (accessed 24 January 2006).

Hiller, H. H. and T. M. Franz (2004) 'New Ties, Old Ties and Lost Ties: The Use of Internet in Diaspora', New Media \& Society, 6(6): 731-752.

Hroch, M. (1985) Social Preconditions of National Revival in Europe, Cambridge: Cambridge University Press.

Kaelble, H. (ed.) (2004) The European Way. European Societies in the $19^{\text {th }}$ and $20^{\text {th }}$ Centuries, Oxford: Berghahn Books.

Kagan, R. (2002) 'Power and Weakness', Policy Review, 113, available at http://www.policyreview.org/JUN02/kagan.html (accessed 3 June 2005).

Kant, I. (1795) 'Perpetual Peace: A Philosophical Essay' in (1891) Kant's Principles of Politics, Including his Essay on Perpetual Peace. A Contribution to Political Science, translated from German by W. Hastie, Edinburgh: Clark, available at http://olldownload.libertyfund.org/EBooks/Kant_0426.pdf (accessed 1 July 2006).

Kennedy, P. and V. Roudometof (eds) (2003) Communities across Bborders: New Immigrants and Transnational Cultures, London: Routledge.

Kraske, M. and A. Langer (2006) 'Art or Porn?', Spiegel Online, January 2, available at http://service.speigel.de/cache/international/0,1518,druck392803,00.html (accessed 16 January 2006).

Lewis, Justin and Karin Wahl-Jorgensen (2005) 'Active citizen or couch potato? Journalism and public opinion’ (98-108) in Allan, S. (ed.) (2005) Journalism: Critical Issues, Open University Press.

Longman, C. and N. Perez-Solorzano (2005) 'The Constitutional Construction of European Values', Working Paper No. 4 presented at the International Symposium 'The Re-Constructions of EU-rope: Social, Political and Cultural Dimensions of Reforming and Enlarging the European Union', Lancaster University, 12-13 May 2005.

Marquand, D. (2004) 'The British-US Axis No Longer Makes Any Sense', The Guardian, February 21, p. 20.

Nakamura, H. (1993) A Comparative History of Ideas, Columbia University Press.

Pecican, O. (2003) Romania si Uniunea Europeana, Cluj-Napoca: Eikon.

Rantanen, T. (2005) The Media and Globalization, London: Sage.

Sabry, T. (2005) 'The Day Moroccans Gave Up Couscous for Satellites: Global

TV, Structures of Feeling, and Mental Migration', Transnational Broadcasting 
Studies, 14 (Spring/Summer), available at

http://www.tbsjournal.com/Archives/Spring05/sabry.html (accessed 15

September 2005).

Scannell, P. (1996) Radio, Television and Modern Life: A Phenomenological Approach, Oxford: Blackwell.

Schlesinger, P. (2003) 'The Babel of Europe? An Essay on Networks and

Communicative Spaces', AREN $A$ Working Paper, 22/03, available at

http://www.arena.uio.no/publications/wp_03_22.pdf (accessed 22

December 2005).

Schlesinger, P. and J.E. Fossum (2005) 'The European Union and the Public

Sphere: A Communicative Space in the Making?', available at

http://www.iue.it/LAW/ResearchTeaching/Cidel/pdf/SchlesingerFossum

.pdf (accessed 1 July 2006).

Siapera, E. (2006) 'Multiculturalism Online. The Internet and the Dilemmas of

Multicultural Politics', Cultural Studies, 9(1): 5-24.

Smith, A. D. (1998) Nationalism and Modernism, London: Routledge.

Trandafoiu, R. (forthcoming) 'Translating Europeanness to the Europeans, a

Common 'Language' in the East and West', in S. Kaitatzi-Whitlock and A.

Baltzis (eds) Innovation and Challenges in the European Media, Thessaloniki:

University Studio Press.

Triandafyllidou, A. (2003) 'Research Note: The Launch of the Euro in the Italian

Media. Representations of Political and Economic Integration', European

Journal of Communication, 18(2): 255-263.

Tsagarousianou, R. (2004) 'Rethinking the Concept of Diaspora: Mobility,

Connectivity and Communication in a Globalised World', Westminster Papers in Communication and Culture, 1(1): 52-65.

Van Hear, N. (1998) New Diasporas. The Mass Exodus, Dispersal and Regrouping of Migrant Communities. London: UCL Press.

Ward, D. (2002) The European Union Democratic Deficit and the Public Sphere: An

Evaluation of EU Media Policy, Amsterdam: IOS Press.

Weber, E. (1979) Peasants into Frenchmen: The Modernization of Rural France 1870-1914, London: Chatto and Windus.

Williams, K. (2005) European Media Studies, London: Arnold. 